\title{
Conservation and In Vitro Propagation of an Endangered Wild Turmeric (Curcuma caesia Roxb.) Species from Sub - Himalayan Terai Region of West Bengal
}

\author{
Sayan Chowdhury ${ }^{1}$, Kumaresh Pal ${ }^{1}$, Moumita Chakraborty ${ }^{2}$, Soumendra Chakraborty ${ }^{2}$, \\ Somnath Mandal ${ }^{1}$, Goutam Kr. Pandit ${ }^{1}$, Soumen Maitra ${ }^{3}$ and Nandita Sahana ${ }^{1 *}$ \\ ${ }^{1}$ Department of Biochemistry, Uttar Banga Krishi Viswavidyalaya, Pundibari-736165, \\ Cooch Behar, West Bengal, India \\ ${ }^{2}$ Department of Genetics and Plant Breeding, Uttar Banga Krishi Viswavidyalaya, \\ Pundibari-736165, Cooch Behar, West Bengal, India \\ ${ }^{3}$ Department of Floriculture, Medicinal and Aromatic Plants, Uttar Banga Krishi \\ Viswavidyalaya, Pundibari-736165, Cooch Behar, West Bengal, India
}

*Corresponding author

Keywords

Curcuma caesia, micro-propagation, explant, in vitro, BAP, IAA, IBA, Kinetin, 2, 4-D

Article Info

\section{Accepted:}

15 January 2020 Available Online: 10 February 2020

\section{A B S T R A C T}

Curcuma caesia Roxb. is a perennial herb with bluish-black rhizome and reportedly harbors medicinal properties. The powder and essential oil of the rhizome of the herb has potential use in pharmaceutical and cosmetic industries. This important wild turmeric species has also been declared as endangered. Conservation and propagation of the black turmeric species by in vitro techniques is of high importance. The present study was conducted to develop an efficient protocol for mass propagation and conservation of Curcuma caesia collected from northern part of West Bengal. Bud from rhizomes as explants was cultured on full strength Murashige and Skoog (MS) medium for 19 days. For multiplication purpose, the explants were transferred either in MS medium supplemented with 6-Benzylaminopurine (BAP) and IAA or Kinetin (KIN) with BAP for 56 days. MS medium supplemented with a combination of BAP $2.0 \mathrm{mg} / \mathrm{L}$ and IAA $0.75 \mathrm{mg} / \mathrm{L}$ gave the highest number (four) of shoots. MS medium supplemented with a combination of $2.0 \mathrm{mg} / \mathrm{L} \mathrm{IBA}$ gave the highest number (twelve) of roots after 28 days. Healthy and complete plants with well-developed roots were hardened, acclimatized and planted in the field successfully with a survival rate of $70 \% .2 .0 \mathrm{mg} / \mathrm{L} \mathrm{2,4-D}$ showed the best result of callus induction for 83 days. 


\section{Introduction}

India is known as a country of spices where nearly sixty three spice crops are grown at various parts of the country. The genus Curcuma has a number of species of which black turmeric (Curcuma caesia) is one of the unexplored wild relative of cultivated Curcuma longa and has immense medicinal potential. This species is native to North-East and Central India. It is a perennial herb with bluish-black colour rhizome (Fig 1A).

The plant of the Curcuma caesia looks similar to Curcuma longa except leaves of Curcuma caesia have a deep red-violet patch, which runs throughout the whole lamina (Fig B and
C). The rhizome has profound medicinal importance and claimed to be useful in treating several diseases like leprosy, bronchitis, asthma, piles, cancer, epilepsy, fever wounds, impotency, fertility, tooth ache and vomiting etc. (Flowers of India, 2005).

Presently this species is said to be under threat of extinction since natural habitat is being destroyed widely through several human activities like industrialization, urbanization etc. Hence it is necessary to take measures for conservation and multiplication of this unique species. The present study focuses on development of an effective in vitro micro propagation method for $C$. caesia using rhizome bud as explants.
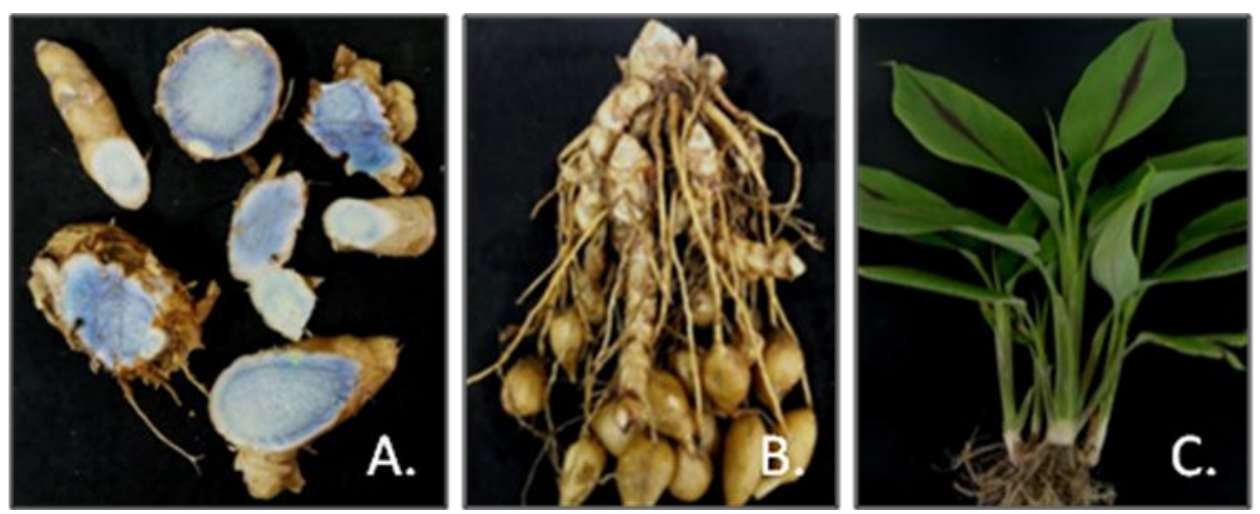

Fig.1(A) Characteristic Bluish colour of Cucuma ceasia rhizome. (B). Mature rhizome and (C). Full grown plants of $C$. caesia.

\section{Materials and Methods}

\section{Collection of the material}

Rhizomes of Curcuma caesia were collected from All India Coordinated Research Project (AICRP) on Spices at Pundibari, Uttar Banga Krishi Viswavidyalaya, Coochbehar, West Bengal, India.

The centre belongs to Terai agro-climatic zone of West Bengal and is situated between $26 \square 19 \square \square 86 \square \square \mathrm{N}$ latitude and $893.5 \square \square \mathrm{E}$ longitude at an altitude of $43.0 \mathrm{~m}$ above mean sea level.

\section{Disinfection of rhizomes}

Each rhizome was sliced into small pieces (3 to $4 \mathrm{~cm}$ ) with at least one bud on them and washed with tap water. The rhizomes were briefly treated with few drops of Tween 20 for one minute and cleaned under running tap water for half an hour.

The explants were thoroughly treated by fungicides and bactericides in following sequence i.e. Bavistin (0.5\%), Plantomycin $(0.05 \%)$ and Rifampicin $(0.2 \%)$ for one hour. They were then rinsed several times with sterile distilled water. Finally, inside the 
laminar air-flow cabinet, surface disinfection was done by $70 \%$ ethanol and buds were treated with $0.1 \%(\mathrm{w} / \mathrm{v})$ mercuric chloride solution for 5 minutes.

\section{Regeneration}

Buds were rinsed with autoclaved distilled water and inoculated on full strength Murashige and Skoog (MS) medium in a test tube or culture bottle. The medium (Murashige and Skoog, 1962) contained 3\% (w/v) sucrose, myo-inositol $100 \mathrm{mg} / \mathrm{L}$ and $0.8 \%(\mathrm{w} / \mathrm{v})$ agar as basal. The $\mathrm{pH}$ of the medium was adjusted to 5.8 before adding agar and was autoclaved at $121^{\circ} \mathrm{C}$ and 105 $\mathrm{kg} / \mathrm{cm}^{2}$ of pressure for 20 minutes.

The inoculated test tubes were shifted to the growth room with room temperature maintained at $25 \pm 1{ }^{\circ} \mathrm{C}$ with $16 \mathrm{~h}$ light and $8 \mathrm{~h}$ dark period with 60 to $70 \%$ relative humidity in the culture room.

The sterilized buds from in vitro derived shoots were cultured on medium containing $\mathrm{KIN}(0.5 \mathrm{mg} / \mathrm{L}), \mathrm{BAP}(1-4 \mathrm{mg} / \mathrm{L})$ and IAA $(0.5-0.75 \mathrm{mg} / \mathrm{L})$ for proliferation and multiplication.

Further these plantlets were cultured on rooting media containing IBA $2.0 \mathrm{mg} / \mathrm{L}$. Ten to fifteen cultures were used per treatment and each treatment was repeated thrice.

\section{Hardening}

Plantlets with well-developed roots were removed from the medium, then washed thoroughly under running tap water to remove adhering solid MS medium, and transplanted to plastic pots containing sterilized soil rites and kept in a 50\% shaded net house. The plants were frequently watered to keep high level of humidity. The fully acclimatized plants were transferred to the field.

\section{Callus Induction}

The callus was induced by inoculating leaf tissues (blade discs, sheath base, sheath top) on a modified MS medium containing kinetin, 2,4-D, myo-inositol, sucrose in different concentration, and agar as solidifying agent. The inoculated materials were cultured in growth room at $25 \pm 2^{\circ} \mathrm{C}$ under a photoperiod of 16/8 hours (light/dark) conditions. The evaluation of callus formation was performed 50 days after inoculation. Regeneration of plantlets from callus was successfully conducted in MS medium supplemented with a combination of $2.0 \mathrm{mg} / \mathrm{L} \mathrm{BAP}$ and $1.0 \mathrm{mg} / \mathrm{L}$ Kinetin.

\section{Results and Discussion}

\section{Effect of growth regulators on callus induction in black turmeric}

Callus induction in black turmeric (C. caesia) was achieved using different combinations of 2,4-D (0.5, 1.0 and $2.0 \mathrm{mg} / \mathrm{L})$ along with Kinetin (1.0 and $2.0 \mathrm{mg} / \mathrm{L})$. Callus induction started after 3 weeks and maximum callus growth was obtained after 83.33 days in the medium supplemented with $2.0 \mathrm{mg} / \mathrm{L}$ of $2,4-$ $\mathrm{D}(31.33 \%)$ followed by $2.0 \mathrm{mg} / \mathrm{L} 2,4-\mathrm{D}+2.0$ $\mathrm{mg} / \mathrm{L}$ Kinetin $(25.00 \%)$. Callus growth was relatively poor $(14.67 \%)$ in the medium containing $1.0 \mathrm{mg} / \mathrm{L} \mathrm{2,4-D} \mathrm{+} 1.0 \mathrm{mg} / \mathrm{L}$ Kinetin (Table 1 and Fig 2A).

The similar type of findings was reported by Singh et al., (2015) and Md Zain (2013). The medium without hormone failed to induce callus even after 7 weeks of culture. Induction of callus was better on MS medium supplemented with 2,4-D alone than 2,4-D and Kinetin combination. In the present study callus formation was successfully induced but the calluses were failed to regenerate to plantlets even after modification of medium. From the present study it was observed that 
2,4-D was the best auxin on the induction of callus than combination of 2,4-D and kinetin in black turmeric.

The present study was carried out to ascertain the in vitro efficacy of different hormones (BAP, Kinetin and IAA) on shoot bud induction of endangered medicinally important herb black turmeric (C. caesia). The basal medium used for shoot bud initiation purpose was MS media with different hormonal supplementations (Table 2 and Fig 2B). The rhizome bud culture resulted that $\mathrm{MS}$ medium containing $2.0 \mathrm{mg} / \mathrm{L} \mathrm{BAP+}$ $0.75 \mathrm{mg} / \mathrm{L}$ IAA responded best followed by $4.0 \mathrm{mg} / \mathrm{L} \mathrm{BAP}$ and $4.0 \mathrm{mg} / \mathrm{L} \mathrm{BAP}+0.5 \mathrm{mg} / \mathrm{L}$ kinetin.

The shoot buds initiated in these treatments within 18 days, 19.33 days and 20 days respectively. No significant difference was found within these five different hormonal supplementations $(3.0 \mathrm{mg} / \mathrm{L} \mathrm{BAP,} 4.0 \mathrm{mg} / \mathrm{L}$ BAP, $4.0 \mathrm{mg} / \mathrm{L} \mathrm{BAP} \mathrm{+} 0.5 \mathrm{mg} / \mathrm{L}$ kinetin, 2.0 $\mathrm{mg} / \mathrm{L} \mathrm{BAP}+0.75 \mathrm{mg} / \mathrm{L}$ IAA and $2.0 \mathrm{mg} / \mathrm{L}$ $\mathrm{BAP}+1.0 \mathrm{mg} / \mathrm{L}$ IAA). Maximum number of multiple shoot induction was observed after 8 weeks of culture.

From the table, it was evident that out of fifteen different combinations, highest induction of rhizome buds were found in medium containing $2.0 \mathrm{mg} / \mathrm{L} \mathrm{BAP}+0.75$ $\mathrm{mg} / \mathrm{L}$ IAA $(60.67 \%)$ within 18 days. In the present investigation, it was observed that with increase in the concentration of IAA above $0.75 \mathrm{mg} / \mathrm{L}$, the rate of shoot multiplication declined.

According to Shahinozzaman et al., (2013) the optimum shoot proliferation was found in case of black turmeric from MS medium containing $3.0 \mu \mathrm{M}$ BA $+0.5 \mu \mathrm{M}$ NAA and produced highest shoots with $4.53 \mathrm{~cm}$ length after 8 weeks of culture.
Effect of different growth regulators on multiple shooting and leaf emergence of black turmeric

After initiation of shoot, the media composition was changed for multiple shoot proliferation. The rhizome buds culture with MS medium supplemented with $2.0 \mathrm{mg} / \mathrm{L}$ BAP $+1.0 \mathrm{mg} / \mathrm{L}$ IAA showed highest shoot multiplication (4.00 shoots/explant) followed by $4.0 \mathrm{mg} / \mathrm{L} \mathrm{BAP}+0.5 \mathrm{mg} / \mathrm{L}$ kinetin within 8 weeks of culture (3.67 shoots/explant) (Table $2)$. With an increase in the concentration of BAP and IAA, the number of shoots per explant increased.

Out of fifteen different treatments, rhizome buds showed best performance in $2.0 \mathrm{mg} / \mathrm{L}$ $\mathrm{BAP}+1.0 \mathrm{mg} / \mathrm{L}$ IAA containing medium in terms of number of shoots/explant. The rhizome bud culture in MS medium in terms of number of leaves/shoot exhibited that MS medium with $1.5 \mathrm{mg} / \mathrm{L} \mathrm{BAP}+0.5 \mathrm{mg} / \mathrm{L} \mathrm{IAA}$ responded best (4.00 leaves/shoot) followed by $2.0 \mathrm{mg} / \mathrm{L} \mathrm{BAP}+1.0 \mathrm{mg} / \mathrm{L}$ IAA and 3.0 $\mathrm{mg} / \mathrm{L} \mathrm{BAP}+0.5 \mathrm{mg} / \mathrm{L}$ kinetin (3.33 leaves/shoot) whereas lowest was observed in full strength MS medium without hormone (1.33 leaves/shoot) (Table 3 and Fig 2C)..

From the present study it was evident that with increase in the concentration of BAP alone, the rate of shoot multiplication increased. But, BAP and IAA combination showed better result than BAP alone.

Analogous findings were reported by Balachandran et al., (1990) who observed that for shoot multiplication of C. caesia $3.0 \mathrm{mg} / \mathrm{L}$ BA supplemented with MS medium was optimum and Ghosh et al., (2013) who reported that MS medium supplemented with $2.5 \mathrm{mg} / \mathrm{L}$ of BAP $+1.5 \mathrm{mg} / \mathrm{L}$ NAA could produce highest shoots with an average height of $7 \mathrm{~cm}$. The well-developed shoots were taken from shoot clumps and transferred to 
root induction medium i.e. full strength MS medium containing different hormonal combinations. MS medium supplemented with a combination of $2.0 \mathrm{mg} / \mathrm{L}$ IBA gave the maximum number (11.67) of roots/shoot followed by $1.5 \mathrm{mg} / \mathrm{L} \mathrm{IBA} \mathrm{(8.67} \mathrm{roots/shoot)}$ while lowest number of roots/shoot (2.33) was found in full strength MS medium without hormone. Out of fifteen different hormonal supplementations, rhizome buds showed best performances in $2.0 \mathrm{mg} / \mathrm{L} \mathrm{IBA}$ containing medium in terms of number of roots/shoot (Table 4 and Fig 2D). Root initials were developed into a good root system within 14-18 days. Healthy rooted plantlets were transferred to the field after hardening. The survival rate of developed plantlets under field condition was 70\% (Fig 2E and F).The present study showed that shoot bud induction, number of shoots/explant, number of leaves/shoot and number of roots/shoot of black turmeric was depended on the growth regulators used as supported by the observations of Singh et al., (2015). It was observed in the present investigation that 2.0 $\mathrm{mg} / \mathrm{L}$ IBA was optimum for the development of sufficient number of roots/shoot. Similar types of results were reported by Shahinozzaman et al., (2013) and Singh et al., (2015).

Table.1 Effect of 2, 4-D and Kinetin on the induction of callus in black turmeric

\begin{tabular}{|c|c|c|c|c|}
\hline \multicolumn{2}{|c|}{$\begin{array}{c}\text { Hormone concentration } \\
(\mathrm{mg} / \mathrm{L})\end{array}$} & \multirow{2}{*}{$\begin{array}{l}\text { Callus induction } \\
\qquad(\%) \\
(\text { mean* } \pm \text { SE) }\end{array}$} & \multirow{2}{*}{$\begin{array}{c}\text { Days of callus } \\
\text { initiation } \\
(\text { mean* } \pm \text { SE) }\end{array}$} & \multirow[t]{2}{*}{$\begin{array}{l}\text { Callus } \\
\text { growth }\end{array}$} \\
\hline 2, 4-D & Kinetin & & & \\
\hline 0.5 & 1.0 & 0.00 & - & - \\
\hline 1.0 & 1.0 & $14.67 \pm 1.080^{\mathrm{e}}$ & $96.33 \pm 1.633^{d}$ & + \\
\hline 2.0 & 1.0 & $16.33 \pm 0.408^{d}$ & $92.00 \pm 1.414^{b c}$ & + \\
\hline 0.5 & 0.0 & 0.00 & - & - \\
\hline 1.0 & 0.0 & $24.00 \pm 0.707^{b}$ & $90.67 \pm 0.816^{b}$ & +++ \\
\hline 2.0 & 0.0 & $31.33 \pm 0.408^{\mathrm{a}}$ & $83.33 \pm 0.408^{a}$ & ++++ \\
\hline 1.0 & 2.0 & $21.67 \pm 0.816^{\mathrm{c}}$ & $91.67 \pm 1.080^{\mathrm{bc}}$ & ++ \\
\hline 2.0 & 2.0 & $25.00 \pm 1.225^{\mathrm{b}}$ & $94.00 \pm 0.707^{c}$ & +++ \\
\hline
\end{tabular}

*Average of three replicates

In vitro micro propagation of black turmeric (C. caesia) was carried out with the help of different auxins and cytokinins (BAP, IAA, IBA, Kinetin and 2,4-D). For induction of multiple shooting of the rhizomes, a combination of BAP + IAA and BAP + Kinetin was used. BAP (6Benzylaminopurine) is a first-generation synthetic cytokinin that is known for its role in plant growth and development responses in tissue culture by stimulating cell division (Zuraida, 2013). IAA is the most common, naturally occurring, plant hormone of the auxin class which helps in cell elongation and cell division for plant growth and development. A higher concentration of IAA above $0.75 \mathrm{mg} / \mathrm{L}$, the rate of shoot multiplication declined. Earlier studies by Bharalee et al., (2005) and Shahinozzaman et al., (2013) reported the effected of IAA in shoot multiplication. In case of root induction only IBA was provided to the cultures. IBA is a plant hormone in the auxin family that is known for its role in root formation in vitro (Ghosh et al., 2013). The dose of 2 ppm IBA supplemented in MS media has given the best root induction in the rhizome cultures. In case of $C$. caesia the combination of BAP + IAA was found better than BAP + Kinetin in multiple shooting. 
Table.2 Effect of BAP, Kinetin and IAA on in vitro shoot bud induction of black turmeric

\begin{tabular}{|c|c|c|c|c|}
\hline \multicolumn{2}{|c|}{$\begin{array}{c}\text { Hormone concentration } \\
(\mathbf{m g} / \mathbf{L})\end{array}$} & $\begin{array}{c}\text { Days for multiple } \\
\text { shoot initiation } \\
\text { (mean* } \pm \text { SE) }\end{array}$ & $\begin{array}{c}\text { Shoot bud } \\
\text { induction }(\%) \\
(\text { mean* }\end{array}$ \\
\cline { 1 - 3 } BAP SE)
\end{tabular}

*Average of three replicates

Table.3 Effect of BAP, Kinetin and IAA on in vitro multiplication of number of Shoots / explants and number of leaves/shoot of black turmeric

\begin{tabular}{|c|c|c|c|c|}
\hline \multicolumn{3}{|c|}{ Hormone concentration $(\mathrm{mg} / \mathrm{L})$} & \multirow{2}{*}{$\begin{array}{l}\text { No. of shoots/ } \\
\text { explant } \\
(\text { mean* } \pm \text { SE })\end{array}$} & \multirow{2}{*}{$\begin{array}{c}\text { No. of leaves/ } \\
\text { shoot } \\
\text { (mean* } \pm \text { SE) }\end{array}$} \\
\hline BAP & Kinetin & IAA & & \\
\hline 0.0 & 0.0 & - & $2.00 \pm 1.225^{b c}$ & $1.67 \pm 0.816^{\mathrm{c}}$ \\
\hline 1.0 & 0.0 & - & $1.67 \pm 0.408^{c}$ & $2.00 \pm 0.000^{b c}$ \\
\hline 1.0 & 0.5 & - & $2.00 \pm 0.000^{b c}$ & $2.67 \pm 0.816^{\mathrm{abc}}$ \\
\hline 2.0 & 0.0 & - & $2.33 \pm 0.408^{a b c}$ & $2.67 \pm 0.408^{a b c}$ \\
\hline 2.0 & 0.5 & - & $2.33 \pm 0.408^{a b c}$ & $2.00 \pm 0.000^{b c}$ \\
\hline 3.0 & 0.0 & - & $2.67 \pm 1.080^{\mathrm{abc}}$ & $2.67 \pm 0.408^{\mathrm{abc}}$ \\
\hline 3.0 & 0.5 & - & $2.67 \pm 0.408^{a b c}$ & $3.33 \pm 0.408^{\mathrm{ab}}$ \\
\hline 4.0 & 0.0 & - & $3.00 \pm 0.707^{\mathrm{abc}}$ & $2.33 \pm 0.408^{b c}$ \\
\hline 4.0 & 0.5 & - & $3.67 \pm 0.408^{a b}$ & $2.67 \pm 1.080^{\mathrm{abc}}$ \\
\hline 0.0 & - & 0.0 & $1.67 \pm 0.816^{c}$ & $1.33 \pm 0.408^{c}$ \\
\hline 0.5 & - & 0.25 & $2.00 \pm 0.000^{b c}$ & $1.67 \pm 0.816^{\mathrm{c}}$ \\
\hline 1.0 & - & 0.25 & $2.67 \pm 0.408^{a b c}$ & $2.00 \pm 0.707^{b c}$ \\
\hline 1.5 & - & 0.5 & $2.67 \pm 0.816^{\mathrm{abc}}$ & $4.00 \pm 0.000^{\mathrm{a}}$ \\
\hline 2.0 & - & 0.75 & $3.33 \pm 0.408^{a b c}$ & $2.67 \pm 0.408^{\mathrm{abc}}$ \\
\hline 2.0 & - & 1.0 & $4.00 \pm 0.707^{\mathrm{a}}$ & $3.33 \pm 0.408^{\mathrm{ab}}$ \\
\hline
\end{tabular}

*Average of three replicates 
Table.4 Effect of BAP, Kinetin, IAA and IBA on in vitro multiplication of number of roots / shoot of black turmeric

\begin{tabular}{|c|c|c|c|c|}
\hline \multicolumn{4}{|c|}{ Hormone concentration (mg/L) } & \multirow{2}{*}{$\begin{array}{l}\text { No. of roots/ shoot } \\
\quad(\text { mean* } \pm \text { SE })\end{array}$} \\
\hline BAP & Kinetin & IAA & IBA & \\
\hline 0.0 & 0.0 & - & 0.0 & $2.67 \pm 1.080^{\mathrm{fg}}$ \\
\hline 0.0 & 0.0 & - & 0.5 & $3.67 \pm 0.408^{\mathrm{efg}}$ \\
\hline 0.0 & 0.5 & - & 0.5 & $4.67 \pm 0.816^{\mathrm{def}}$ \\
\hline 0.0 & 0.0 & - & 1.0 & $6.00 \pm 0.707^{\mathrm{cd}}$ \\
\hline 0.0 & 0.5 & - & 1.0 & $4.33 \pm 1.633^{\operatorname{defg}}$ \\
\hline 1.0 & 0.0 & - & 1.5 & $5.00 \pm 0.000^{\mathrm{de}}$ \\
\hline $\mathbf{0 . 0}$ & 0.5 & - & 1.5 & $4.00 \pm 0.000^{\operatorname{defg}}$ \\
\hline 0.0 & 0.0 & - & 2.0 & $8.33 \pm 0.816^{b}$ \\
\hline 1.0 & 0.0 & - & 2.0 & $5.67 \pm 0.408^{\text {cde }}$ \\
\hline 0.0 & - & 0.0 & 0.0 & $2.33 \pm 1.080^{\mathrm{g}}$ \\
\hline 0.0 & - & 0.0 & 1.0 & $6.00 \pm 1.225^{\mathrm{cd}}$ \\
\hline 1.0 & - & 0.0 & 1.0 & $5.00 \pm 0.707^{\mathrm{de}}$ \\
\hline 0.0 & - & 0.0 & 1.5 & $8.67 \pm 0.408^{b}$ \\
\hline 0.0 & - & 0.5 & 1.5 & $7.33 \pm 0.408^{b c}$ \\
\hline 0.0 & - & 0.0 & 2.0 & $11.67 \pm 0.408^{\mathrm{a}}$ \\
\hline
\end{tabular}

*Average of three replicates
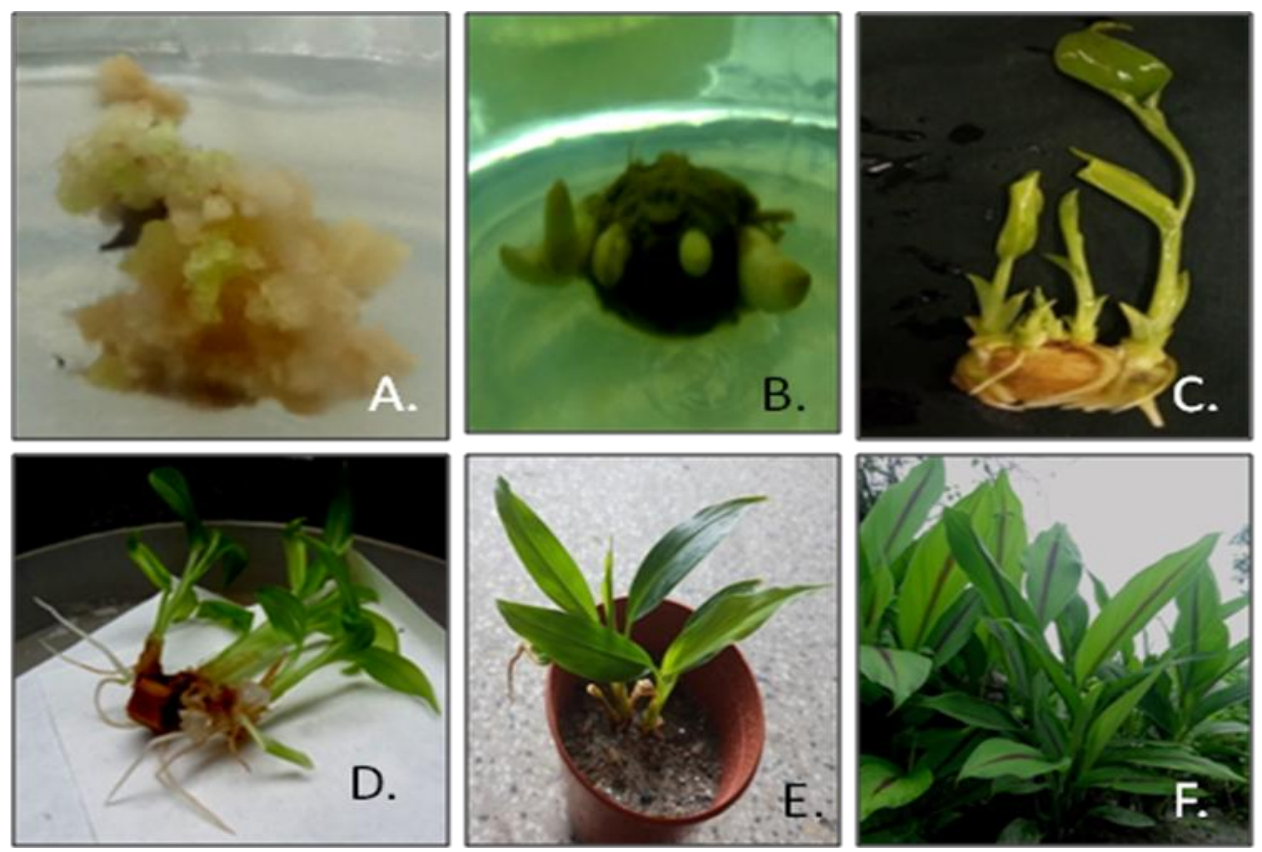

Fig.2 Different stages of in vitro micro propagation of black turmeric (C. caesia)

(A) The induction of callus with leaf tissue after 65 days $(2.0 \mathrm{mg} / \mathrm{L} \mathrm{2,4-D)}$

(B) Shoot bud initiation after 15 days (without hormone),

(C) Shoot initiation from bud after 32 days

(D) Root induction after 60 days

(E) Hardening was done after 90 days (plastic pots with soilrite)

(F) Developed plantlets transferred to the field after 120 days 
In case of callus cultures combination of 2,4$\mathrm{D}$ and Kinetin was tested. 2,4-D is a synthetic auxin and has prominent role in dedifferentiation of the plant tissues to induce callus (Prakash et al., 2004). Kinetin is a type of cytokinin that promotes regeneration of plantlets from callus. 2 ppm 2,4-D without any kinetin was found to be the best in inducing callus. Even after application of kinetin in increasing concentration absolutely no regeneration of root initiation was notice in the calluses derived from turmeric leaves.

Curcuma caesia is one of the endangered medicinally important herb that has not been investigated thoroughly for its biochemical potential till date. The conservation and mass multiplication of this important herb has been addressed in the present study using the micro propagation techniques. In the present study, a suitable technique for clonal propagation of black turmeric (C. caesia) has been developed for getting disease free and homogeneous planting material for off season and whole year cultivation in a cost effective manner for the benefit of the farmers.

The basal medium (usually MS medium) with combination of different plant hormones werer tested for shoot bud induction, multiple shoot regeneration, leaf emergence and root initiation and ability of callus induction using different plant parts as explant. In the present study, the micro propagation protocol of $C$. caesia was established from rhizome bud explants by induction of multiple shooting.

Curcuma caesia rhizome buds showed best performance in $2.0 \mathrm{mg} / \mathrm{L} \mathrm{BAP}+0.75 \mathrm{mg} / \mathrm{L}$ IAA containing MS medium in terms of shoot bud induction percentage (60.67) within 18 days. MS medium with $2.0 \mathrm{mg} / \mathrm{L} \mathrm{BAP}+1.0$ $\mathrm{mg} / \mathrm{L}$ IAA (4.00) responded best in case of formation of number of shoots/explant (4.00) whereas maximum number of leaves/shoot (4.00) was found in medium containing 1.5 $\mathrm{mg} / \mathrm{L} \mathrm{BAP}+0.5 \mathrm{mg} / \mathrm{L}$ IAA. MS medium supplemented with a combination of $2.0 \mathrm{mg} / \mathrm{L}$ IBA gave the highest number of roots while $2.0 \mathrm{mg} / \mathrm{L} \mathrm{2,4-D}$ showed the best result of callus induction. But regeneration of plantlets from the callus culture through medium modifications could not be done successfully.

From the study it can be inferred that shoot multiplication can be considered as the best suitable tissue culture practices for the micro propagation of Curcuma caesia. It may also be noted that the rhizome size needed for micro propagation of turmeric is smaller than conventional cultivation method implying that requirement of rhizomes will be much less than rhizome propagation method. This micro propagation protocol can be a viable option for generation of large amount of disease free true to the type propagule of black turmeric around the year and also for conservation of this endangered species.

\section{References}

Balachandran, S.M., Bhat, S.R. and Chandel, K.P.S. 1990. In vitro clonal multiplication of turmeric (Curcuma sp.) and ginger (Zingiber officinale Rose.). Plant Cell Reports, 8: 521-524.

Bharalee. R., Das, A. and Kalita, M.C. 2005. In vitro clonal propagation of Curcuma caesia Roxb. and Curcuma zedoaria Rose. from rhizome bud explants. Journal of Plant

Biochemistry and Biotechnology, $\quad 14:$ 61-63.

Flowers of India 2005. Black Turmeric. [Online]. Available at: http://www.flowersofindia.net/catalog/sl ides/Black\%20Turmeric.html [Accessed 12 February 2012].

Ghosh, A., Chatterjee, P. and Ghosh, P. 2013. A protocol for rapid propagation of genetically true to type Indian turmeric (Curcuma longa L.) through in vitro 
culture technique. Advances in Applied Science Research, 4: 39-45.

Md Zain N. E. B. 2013. In vitro propagation of Curcuma caesia Roxb. pp 1-24. University Malaysia Sarawak, Kota Samarahan, Sarawak, Malaysia.

Murashige, T. and Skoog, F. 1962. A revised medium for rapid growth and bioassays with tobacco tissue cultures. Plant Physiology, 15: 473-497.

Prakash, S., Elangomathavan, R., Seshadri, S., Kathiravan, K. and Ignacimuthu, S. 2004. Efficient regeneration of Curcuma amada Roxb. plantlets from rhizome and leaf sheath explants. Plant Cell Tissue and Organ Culture, 78: 159-165.
Shahinozzaman, M., Ferdous, M.M., Faruq, M.O., Azad, M.A.K. and Amin, M.N. 2013. Micro propagation of black turmeric (Curcuma caesia Roxb.) through in vitro culture of rhizome bud explants. Journal of Central European Agriculture, 14: 110-115.

Singh, W.R.C., Singh, H.B., Devil, S.S., Singh, W.N., Singh, N.M. and Devi, Y.P. 2015. Conservation of Curcuma caesia by in vitro techniques. Helix, 34: 708-713.

Zuraida, A.R. 2013. Improved in vitro propagation of Curcuma caesia, a valuable medicinal plant. Journal of tropical agriculture and food science, 41: 273-281.

\section{How to cite this article:}

Sayan Chowdhury, Kumaresh Pal, Moumita Chakraborty, Soumendra Chakraborty, Somnath Mandal, Goutam Kr. Pandit, Soumen Maitra and Nandita Sahana. 2020. Conservation and In Vitro Propagation of an Endangered Wild Turmeric (Curcuma Caesia Roxb.) Species from Sub - Himalayan Terai Region of West Bengal. Int.J.Curr.Microbiol.App.Sci. 9(02): 2132-2140. doi: https://doi.org/10.20546/ijcmas.2020.902.242 